\title{
Neuroprotection through Delivery of Glial Cell Line-Derived Neurotrophic Factor by Neural Stem Cells in a Mouse Model of Parkinson's Disease
}

\author{
Peter Åkerud, ${ }^{1}$ Josep M. Canals, ${ }^{1}$ Evan Y. Snyder, ${ }^{2}$ and Ernest Arenas ${ }^{1}$ \\ ${ }^{1}$ Laboratory of Molecular Neurobiology, Department of Medical Biochemistry and Biophysics, Karolinska Institute, S- \\ 17177 Stockholm, Sweden, and 2Departments of Neurology, Pediatrics and Neurosurgery, Harvard Medical School and \\ Division of Neuroscience, Children's Hospital, Boston, Massachusetts 02115
}

Neural stem cells (NSCs) have been proposed as tools for treating neurodegeneration because of their capacity to give rise to cell types appropriate to the structure in which they are grafted. In the present work, we explore the ability of NSCs to stably express transgenes and locally deliver soluble molecules with neuroprotective activity, such as glial cell line-derived neurotrophic factor (GDNF). NSCs engineered to release GDNF engrafted well in the host striatum, integrated and gave rise to neurons, astrocytes, and oligodendrocytes, and maintained stable high levels of GDNF expression for at least 4 months. The therapeutic potential of intrastriatal GDNF-NSCs grafts

Neurodegenerative disorders are characterized by a progressive and specific loss of neurons. In human Parkinson's disease (PD), the second most common neurodegenerative disorder, clinical symptoms appear after 50-60\% neuronal loss has occurred in the substantia nigra (McGeer et al., 1988). It is this decrease in neuronal number, and the associated massive (80\%) depletion of striatal dopamine levels (Bernheimer et al., 1973), that produces the characteristic tremor, rigidity, and hypokinesia of the disorder (Carlsson, 1993; Hornykiewicz, 1993). Current treatment strategies for PD focus on restoring the depletion of dopamine, generally through the administration of the dopamine precursor L-DOPA. However, because this treatment does not address the cause of the disorder or the progressive death of dopaminergic neurons, such therapy is destined to provide only temporary relief of symptoms (Olanow and Tatton, 1999).

In recent years, several therapeutic strategies have been proposed that directly address cell loss in neurodegenerative diseases

\footnotetext{
Received April 11, 2001; revised July 9, 2001; accepted July 27, 2001.

This work was supported by the European Commission, the Swedish Medical Research Council, the Swedish Foundation for Strategic Research, the Karolinska Institute, and the Petrus och Augusta Hedlunds, Jeanssonska, Kapten Arthur Eriksson, and Axel och Signe Lagermans Foundations. E.Y.S was supported by grants from the National Institute of Neurological Diseases and Stroke and The Parkinson's Action Network. J.M.C. was supported by a short-term European Molecular Biology Organization and a Human Frontier Science Program fellowships. We thank Dr. Joseph Wagner for critical reading of this manuscript, Lotta Johansson for secretarial help, and Annika Ahlsen for additional assistance.

Requests for parental c17.2 cells should be addressed to Evan Y. Snyder. E-mail: snyder@a1.tch.harvard.edu.

Correspondence and requests for materials and GDNF-c17.2 cells should be addressed to Ernest Arenas, Laboratory of Molecular Neurobiology, Department of Medical Biochemistry and Biophysics, Berzeliusväg 3, Karolinska Institute, S-17177 Stockholm, Sweden. E-mail: ernest@cajal.mbb.ki.se.

J. M. Canals's present address: Department of Cell Biology and Pathology, Facultat de Medicina, Universitat de Barcelona, Institut de Investigacions Biomèdiques August Pi i Sunyer, Casanova 143, 08036 Barcelona, Spain.

Copyright (C) 2001 Society for Neuroscience $\quad 0270-6474 / 01 / 218108-11 \$ 15.00 / 0$
}

was tested in a mouse 6-hydroxydopamine model of Parkinson's disease. We found that GDNF-NSCs prevented the degeneration of dopaminergic neurons in the substantia nigra and reduced behavioral impairment in these animals. Thus, our results demonstrate that NSCs efficiently express therapeutic levels of GDNF in vivo, suggesting a use for NSCs engineered to release neuroprotective molecules in the treatment of neurodegenerative disorders, including Parkinson's disease.

Key words: dopaminergic neurons; glial cell line-derived neurotrophic factor; GDNF; neuroregeneration; neurotrophic factors; striatum; transplantation
(Dunnett and Björklund, 1999). Two of the most promising are the direct replacement of dead or damaged neurons via transplantation of dopamine neurons and the prevention of neuronal death with neurotrophic molecules. Intrastriatal (caudate putamen) grafting of embryonic mesencephalic tissue has been found to efficiently restore dopaminergic function in PD patients (Olanow et al., 1996; Kordower et al., 1998; Lindvall, 1999; Piccini et al., 1999). More recently, embryonic mesencephalic progenitors (Ling et al., 1998; Studer et al., 1998, 2000), neural stem cells (NSCs) (Carpenter et al., 1999; Daadi and Weiss, 1999; Ostenfeld et al., 2000), engineered NSCs to differentiate in a coordinated manner into dopaminergic neurons (Wagner et al., 1999) and embryonic stem cells (Kawasaki et al., 2000; Lee et al., 2000), have been proposed as therapeutic tools in dopamine cell replacement for PD. However, these strategies still face difficulties regarding their large-scale implementation, in part because of the poor survival of dopamine cells (Björklund and Lindvall, 2000). Thus, both cell replacement and neuroprotective strategies for PD could benefit from progress in the application of neuroprotective molecules to enhance the survival of grafted and/or endogenous dopaminergic neurons.

Strategies using neurotrophic molecules focus on preventing the progressive loss of neurons, maintaining neuronal connections and function (neuroprotection), and inducing additional regenerative responses in neurons such as increased neurotransmitter turnover and/or axonal sprouting (neuroregeneration). Up to date, several therapeutic strategies to deliver neurotrophic factors in animal models of Parkinson's disease have been explored. These include the infusion of protein (Beck et al., 1995; Boewencamp et al., 1995; Kearns and Gash, 1995; Sauer et al., 1995; Tomac et al., 1995; Gash et al., 1996), the implantation of polymer encapsulated cells (Lindner et al., 1995), the injection of viruses (Choi-Lundberg et al., 1997; Mandel et al., 1997, 1999; 
Bohn et al., 1999; Bensadoun et al., 2000, Kirik et al., 2000; Kordower et al., 2000), and the grafting of engineered neural stem or progenitor cells (Martínez-Serrano and Björklund, 1997). However, the delivery of glial cell line-derived neurotrophic factor (GDNF), a potent neurotrophic factor for substantia nigra dopaminergic neurons (Lin et al., 1993; Beck et al., 1995; Tomac et al., 1995; Åkerud et al., 1999), by neural stem cells has not yet been tested as a candidate therapeutic approach to Parkinson's disease.

In the present study, we examine whether NSCs, for their proliferative potential in vitro and their capacity to give rise to regionally specific cell types that integrate in the tissue in which they are grafted in vivo (Snyder et al., 1992; Snyder and Macklis, 1996; Weiss et al., 1996; Martínez-Serrano and Björklund, 1997; McKay, 1997; Gage, 2000), could constitute an appropriate tool to deliver neurotrophic factors in a mice model of PD. Thus, our study exploits the known activity of neurotrophic molecules and the long-term integration ability of transplanted NSCs to develop a local and stable delivery system of neurotrophic factors for PD. Our approach has been to engineer a stable clone of NSCs (c17.2 cells; Snyder et al., 1992) to release GDNF. Our results show that NSCs expressing GDNF are able to engraft in the lesioned striatum, give rise to neurons, astrocytes, and oligodendrocytes, deliver GDNF for at least 4 months, and prevent the loss of dopaminergic neurons and the behavioral impairment of mice in a model of PD.

\section{MATERIALS AND METHODS}

Cell culture. c17.2 NSCs and its derivatives were grown in DMEM supplemented with $10 \%$ fetal calf serum, $5 \%$ horse serum, 2 mM glutamine, and $20 \mu \mathrm{g} / \mathrm{ml}$ gentamicin (all from Life Technologies, Grand Island, NY) on uncoated $10 \mathrm{~cm}$ culture dishes (Falcon, Franklin Lakes, NJ) and passaged as described previously (Snyder et al., 1992).

Construction of the GDNF-c17.2 cell line. An IRES-bleomycin resistance gene SacI fragment from pIRESbleo (Clontech, Palo Alto, CA) was cloned into the blunted EcoRI site of the pCAGGS expression vector (Niwa et al., 1991). Then a rat GDNF cDNA was cloned into the EcoRV site of the pCAGGS-IRES-bleo expression vector and used for transfection. c17.2 cells were transfected with the pCAGGS-GDNF-IRES-bleo (pCAGGS-GIB) expression vector or the mock control vector, pCAGGS-IRES-bleo (pCAGGS-IB), using the calcium phosphate-glycerol technique. Transfection, selection, isolation, and amplification of the GDNF-c17.2 or the mock-transfected MT-c17.2 clones were performed as described previously (Arenas et al., 1995). In brief, the Ca-phosphateDNA precipitate was added to the cells for $8 \mathrm{hr}$ before glycerol shock. Selection with bleomycin started $36 \mathrm{hr}$ after the glycerol shock. Two weeks later, single colonies were picked, propagated, and characterized for mRNA and protein expression, as described in the following sections. c17.2 derivatives were characterized in the undifferentiated state (in the culture media mentioned above) and, after differentiation in N2 medium [consisting of a 1:1 mixture of F12 and DMEM containing $10 \mathrm{ng} / \mathrm{ml}$ insulin, $100 \mu \mathrm{g} / \mathrm{ml}$ transferrin, $100 \mu \mathrm{M}$ putrescine, $20 \mathrm{~nm}$ progesterone, 30 nM selenium, $6 \mathrm{mg} / \mathrm{ml}$ glucose, and $1 \mathrm{mg} / \mathrm{ml}$ bovine serum albumin (BSA)], in poly-D-lysine (Sigma, St. Louis, MO)-coated $10 \mathrm{~cm}$ culture dishes.

GDNF ribonuclease protection assay. Assays were performed using the RPA II Ribonuclease Protection Assay kit (Ambion, Austin, TX), following the recommendations of the manufacturer. A $368 \mathrm{bp}$ antisense GDNF cRNA probe (Trupp et al., 1995) was hybridized with $10 \mu \mathrm{g}$ of total RNA extracted from $\mathrm{c} 17.2$ cells proliferating, differentiating for 1 week in vitro, or from the striatum, $15 \mathrm{~d}$ after grafting. Protected cRNA fragments were separated on a polyacrylamide gel as described previously (Trupp et al., 1995). The intensity of the labeling was quantified with a phosphoimager MD Storm 840 (Molecular Dynamics, Sunnyvale, $\mathrm{CA}$ ), and GDNF was standardized to the content of glyceraldehyde-3phosphate dehydrogenase (GAPDH) in every sample, as described previously (Trupp et al., 1995).

GDNF ELISA. The production of GDNF protein was analyzed in c17.2 and GDNF-c17.2 cell lines grown in N2 medium for $12 \mathrm{hr}$. Con- ditioned media was collected and analyzed with a GDNF ELISA kit (Promega, Madison, WI) according to the recommendations of the manufacturer. A standard curve of pure GDNF protein provided in the kit was used to quantify the production of GDNF by the cells.

LacZ PCR. Striata from the grafted brains were dissected out, and DNA was extracted by a deproteinization method as described previously (Laird et al., 1991) and resuspended in $100 \mu$ l of nuclease-free $\mathrm{H}_{2} \mathrm{O}$. Extracted DNA $(0.5 \mu \mathrm{l})$ was mixed with $99.5 \mu \mathrm{l}$ of PCR reaction mixture: $1 \times$ PCR buffer (Promega), $4 \mathrm{~mm} \mathrm{MgCl}_{2}, 200 \mu \mathrm{M}$ dNTPs, and 1 $\mu \mathrm{l}$ of the Lac $\mathrm{Z}$ primers. The two Lac $\mathrm{Z}$ primers used, Lac-Z560 (5'TCCTGAGGCCGATACTGTCGTC3') and Lac-Z950 (TGCCGCTCATCCGCCACATATC3'), annealed to Lac Z (GenBank accession number L08936) and gave a PCR product of $388 \mathrm{bp}$. The amplified fragments were separated in a $2 \%$ agarose gel and visualized with ethidium bromide.

Surgery and transplantation. Male wild-type or nude CD-1 mice (25-35 gm; Charles River, Uppsala, Sweden) were housed and treated according to the guidelines of the European Community $(86 / 609 / \mathrm{EEC})$ and the Society for Neuroscience, and all experiments were approved by the local ethical committee. The animals were anesthetized with pentobarbital (60 $\mathrm{mg} / \mathrm{kg}$, i.p.). $\mathrm{c} 17.2$ and its derivatives (in the proliferative state) were washed twice with serum-free DMEM, detached with a cell lifter (Costar, Cambridge, MA), dissociated with a fire-polished Pasteur pipette, pelleted, and resuspended at a concentration of $250,000 \mathrm{cells} / \mu \mathrm{l}$. A total of 500,000 cells were injected in four locations at the following coordinates (in millimeters) with the incisor bar at -3 : anteroposterior (AP) (bregma), 0.8; lateral (L), 1.8; dorsoventral (DV) (dura), -2.55 and -2.75 ; AP (bregma), 0.3; L, 2.0; DV (dura), -2.55 and -2.75 . Sixteen days after grafting, some of the mice were reanesthetized and injected with $4 \mu \mathrm{g}$ of 6-hydroxydopamine (6-OHDA) (Sigma) in the striatum, at the following coordinates (in millimeters): AP (bregma), 0.5; L, 1.9; DV, -2.65 ; with the incisor bar at -3 .

In some experiments, the cells were prelabeled with either ${ }^{3} \mathrm{H}$ thymidine $(185 \mathrm{GBq} / \mathrm{mmol}, 0.25 \mu \mathrm{Ci} / \mathrm{ml})$ for $48 \mathrm{hr}$ or DiI $(25 \mu \mathrm{g} / \mathrm{ml})$ for $2-4 \mathrm{hr}$. Both labeling procedures resulted in $100 \%$ labeled cells, as assessed by autoradiography or fluorescence microscopy, respectively. As control for lateral transfer of labeling, labeled cells were killed by five to six cycles of freezing and thawing before grafting. Replating of the cells showed no viable cells after freezing and thawing, but when grafted, resulted in multiple labeled cells in and around the graft, suggesting that either labels were transferred to the host brain. Thus, in the present study, all c17.2 cell variants were exclusively traced by immunohistochemistry, in situ hybridization (ISH), and/or PCR to detect the cellautonomous genetic markers in the grafted cells.

Histology. Mice were transcardially perfused with ice-cooled $4 \%$ paraformaldehyde (PFA). Brains were post-fixed for $0-2 \mathrm{hr}$, embedded in $10 \%$ sucrose for $24 \mathrm{hr}$, and frozen on dry ice-cooled isopentane. Serial cryostat sections (14 $\mu \mathrm{m}$ thick) through the entire substantia nigra and striatum were obtained every $200 \mu \mathrm{m}$.

Sections through the striatum were incubated at $4 \mathrm{C}^{\circ}$ overnight with one of the following antibodies in dilution buffer: rabbit anti- $\beta$ galactosidase ( $\beta$-Gal), 1:250 (Cappell-Worthington, Durham, NC); rabbit anti-glial fibrillary acidic protein (GFAP), 1:500 (Dako, Glostrup, Denmark); mouse anti-CNPase, 1:250 (Boehringer Mannheim, Mannheim, Germany); mouse anti-NeuN, 1:100 (Chemicon, Temecula, CA); mouse anti-rat 401 (for nestin), $3 \mu \mathrm{g} / \mathrm{ml}$ (Developmental Studies Hybridoma Bank, University of Iowa, Iowa City, IA); and goat-anti GDNF, 1:20 (R \& D Systems, Minneapolis, MN) in dilution buffer (PBS containing $3 \%$ BSA and $0.3 \%$ Triton X-100). After washing, sections were incubated for 1-3 $\mathrm{hr}$ with the appropriate secondary antibodies: a goat anti-rabbit fluorescein isothiocyanate-conjugated antibody, 1:100 (Vector Laboratories, Burlingame, CA); a donkey anti-mouse rhodamine antibody, 1:200 (Jackson ImmunoResearch, West Grove, PA); or a biotinylated rabbit anti-goat IgG, 1:500 (Vector Laboratories), which was detected by incubation with avidin fluorescein isothiocyanate, 1:500 (Vector Laboratories) for $1 \mathrm{hr}$. $\beta$-Galactosidase activity was detected by incubation of the tissue in 5-bromo-4-chlore-3-indoyl $\beta$-D-galactosidase (X-Gal) as described previously (Snyder et al., 1992).

Sections through the substantia nigra and the striatum of 6-OHDAlesioned animals were processed for tyrosine hydroxylase $(\mathrm{TH}) \mathrm{immu}-$ nohistochemistry using a mouse anti-TH antibody (1:1000; Incstar, Stillwater, MN) and donkey anti-mouse rhodamine antibody (1:200; Jackson ImmunoResearch). Neurons through the entire substantia nigra were counted in serial sections, every $200 \mu \mathrm{m}$, in five to seven animals per experimental group. Neurons showing a clear TH-positive cytoplasm 
surrounding a nonstained nucleus were counted as positive in blind determinations using a Zeiss (Oberkochen, Germany) Axioplan 2 microscope. TH immunoreactivity was also examined in the striatum.

Double immunostainings of striatal sections with $\beta$-Gal/GFAP or GDNF/NeuN antibodies were performed sequentially; first, $\beta$-Gal or GDNF were detected, and then GFAP or NeuN immunohistochemistry was performed. $\beta$-Gal/NeuN, $\beta$-Gal/CNPase, GDNF/GFAP, and GDNF/CNPase double immunohistochemistry of striatal sections and TH/GDNF double immunohistochemistry in sections through the substantia nigra were performed by simultaneous incubation of the sections with the two primary antibodies first and the two secondary antibodies afterward. The specificity of the stainings was confirmed by comparison of the double stainings with the single stained tissue and by omission of the primary antibody.

The position that oligodendrocytes derived from GDNF-c17.2 and MT-c17.2 cells occupied with respect to CNPase-positive white matter fiber bundles of the internal capsule was assessed in striatal sections. Only cells showing clear double-labeled GDNF/CNPase or $\beta$-Gal/CNPase somas surrounding unlabeled nuclei at $40 \times$ magnification were included in the study. Fifty-five randomly chosen cells in fields adjacent to the graft site were analyzed in each grafted brain, in three animals per condition.

In situ hybridization. For ISH, either PFA-perfused or fresh frozen tissue was used. ISH with ${ }^{35}$ S-labeled riboprobes was performed as described previously (Trupp et al., 1997). In brief, sections were fixed for $15 \mathrm{~min}$ in ice-cooled 4\% PFA and rinsed three times in PBS. Tissue was deproteinazed in $0.2 \mathrm{M} \mathrm{HCl}$ for $10 \mathrm{~min}$, acetylated with $0.25 \%$ acetic anhydride in $0.1 \mathrm{~m}$ triethanolamine for $20 \mathrm{~min}$, and dehydrated in increasing concentrations of ethanol. Slides were incubated $16 \mathrm{hr}$ in a humidified chamber at $53^{\circ} \mathrm{C}$ with $10^{6} \mathrm{cpm}$ of probe in $200 \mu \mathrm{l}$ of hybridization cocktail. All of the washes were performed at $62^{\circ} \mathrm{C}$ : first, two washes of $15 \mathrm{~min}$ in $1 \times \mathrm{SSC}, 30 \mathrm{~min}$ in $50 \%$ formamide and $0.5 \times \mathrm{SSC}$, and $15 \mathrm{~min}$ in $1 \times \mathrm{SSC}$; then, $30 \mathrm{~min}$ RNaseA treatment $(40 \mu \mathrm{g} / \mathrm{ml})$ at $37^{\circ} \mathrm{C}$ and two washes of $15 \mathrm{~min}$ in $1 \times$ SSC before dehydration in ethanol and air drying. Slides were first exposed to $\beta$-Max x-ray film (Amersham Pharmacia Biotech, Buckinghamshire, UK) for 12-20 d. Subsequently, the slides were dipped in NTB-2 photoemulsion (Eastman Kodak, Rochester, NY) diluted 1:1 in water, exposed at $4^{\circ} \mathrm{C}$ for $6-8$ weeks, developed with D19 (Eastman Kodak), fixed with AL-4 (Agfa Gevaert, Kista, Sweden), and counterstained with thionin.

Behavioral testing. Behavioral testing was performed $12 \mathrm{~d}$ after lesioning. Mice were injected subcutaneously with apomorphine $(0.5 \mathrm{mg} / \mathrm{kg})$. Ten minutes after injection, the number of rotations were scored for 5 min, an interval of time that gives a very stable response (Winkler and Weiss, 1996). One or $2 \mathrm{~d}$ later, the mice were assessed for amphetamineinduced turning behavior (Barneoud et al., 1995). Amphetamine (2.5 $\mathrm{mg} / \mathrm{kg}$ ) was injected intraperitoneally, and the number of rotations was scored for $3 \mathrm{~min}$ at 15,30 , and $45 \mathrm{~min}$ after injection. The values were expressed as net total numbers of full turns.

\section{RESULTS}

\section{Engineering and characterization of GDNF expression in NSCs}

c17.2 mouse NSCs were transfected with the pCAGGS-GIB expression vector (GDNF-c17.2 cells) (Fig. 1A) or the pCAGGS-IB vector (MT-c17.2 cells). c17.2, GDNF-c17.2, and MT-c17.2 clones showed similar morphology, survival, and proliferation rate in the undifferentiated state. Initially, we examined GDNF mRNA expression by ribonuclease protection assay (RPA) in undifferentiated, proliferating individual clones (Fig. $1 B)$. To verify stability of transgene expression after differentiation in vitro, the highest GDNF expressor (GDNF-c17.2 cell line) and a randomly chosen mock clone (MT-c17.2 cell line) were subsequently tested for expression of GDNF after culture in serum-free medium for 1 week. RPA analysis of these cells showed persistent high levels of GDNF mRNA expression in the GDNF-c17.2 clone and low levels in the MT-c17.2 clone (Fig. $1 C$ ), suggesting that no downregulation of transgene expression was occurring in vitro. The increased expression of GDNF mRNA did not appear to deleteriously affect the cells, because all GDNF-c17.2 clones analyzed had similar morphologies to paren-
A

\begin{tabular}{|l|l|l|l|l|l|l|}
\hline $\begin{array}{c}\text { CMV-IE } \\
\text { enhancer }\end{array}$ & $\begin{array}{l}\beta \text {-actin } \\
\text { promoter }\end{array}$ & $\begin{array}{c}\text { rGDNF } \\
\text { cDNA }\end{array}$ & IVS & IRES & Bleomycinr & $\begin{array}{l}\beta \text {-globin } \\
\text { PolyA }\end{array}$ \\
\hline
\end{tabular}

B

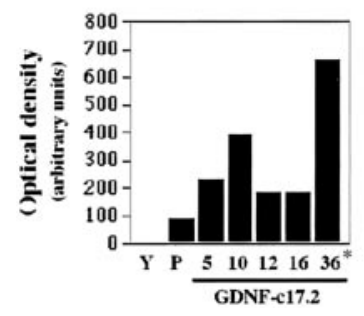

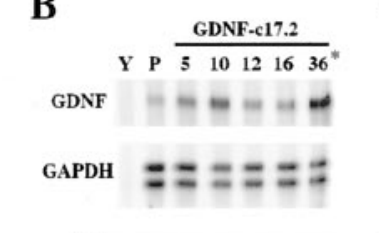
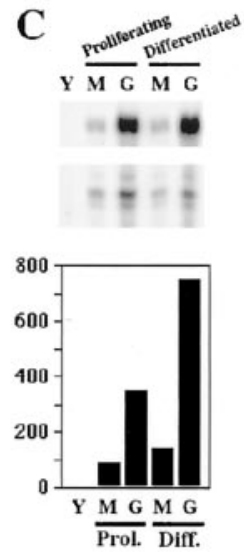

D

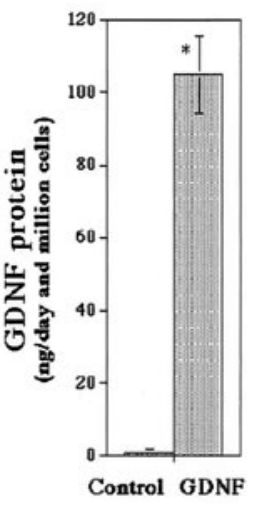

Figure 1. Establishment of a GDNF-overexpressing neural stem cell line. $A$, Schematic representation of the pCAGGS-GIB expression vector that was used for transfection of the c17.2 cells. A rat GDNF cDNA and a mini-intron IRES-bleo resistance gene fragment were cloned after the $\beta$-actin promoter and a CMV-immediate early $(C M V$ - IE) enhancer, in the pCAGGS vector. $B$ and $C$ show two representative experiments, in which GDNF mRNA was analyzed by RPA in control and GDNFtransfected cell lines. IVS, Synthetic intron. $B$, GDNF mRNA expression was determined in the parental c17.2 cell line $(P)$ and five clones $(5,10$, $12,16,36)$ transfected with the pCAGGS-GIB construct. Yeast tRNA $(Y)$ was used as a negative control. Clone 36, the highest expressor, was named GDNF-c17.2 and further characterized. $C$, GDNF mRNA expression was also examined in proliferating and differentiated (in N2 medium for 1 week) MT-c17.2 control cells $(M)$ and the GDNF-c17.2 cells $(G)$. Note that the difference in GDNF mRNA expression between the MTc17.2 and the GDNF-c17.2 cell lines is even greater after differentiation than while proliferating. $D$, ELISA analysis of supernatants from proliferating cells in vitro showed that the control cells (Control; c17.2 or MT-c17.2) released $<1 \mathrm{ng}$ of GDNF per $10^{6}$ cells in $1 \mathrm{~d}$, whereas the GDNF-c17.2 cell line produced $\sim 100 \mathrm{ng}$ of GDNF per $10^{6}$ cells in $1 \mathrm{~d}$ $\left(n=3-4 ;{ }^{*} p<0.0001\right.$; unpaired Student's $t$ test $)$.

tal and MT-c17.2 cell lines after differentiation in N2 media, in the absence of mitogen. To test whether increased levels of mRNA resulted in increased, sustained release of GDNF protein, we quantified the amount of GDNF protein secreted in the media by ELISA. Whereas the parental c17.2 and MT-c17.2 cell lines released $<1 \mathrm{ng}$ of GDNF per $10^{6}$ cells in $1 \mathrm{~d}$, the selected GDNF-c17.2 clone released $\sim 100 \mathrm{ng}$ of GDNF per $10^{6}$ cells in $1 \mathrm{~d}$ (Fig. 1D).

\section{Detection of NSCs after intrastriatal grafting in vivo}

Because transplanted NSCs disperse, integrate, and assume local phenotypes among endogenous host cells, reliable tracing becomes a key issue. The parental c17.2 carries a $\beta$-galactosidase reporter that makes their identification by X-Gal histochemistry or anti- $\beta$-gal immunohistochemistry possible. Whereas MT-c17.2 cells expressed $\beta$-galactosidase at early (Fig. $2 A$ ) and late (Fig. $3 E, G)$ postgrafting time points, we found a downregulation of this reporter in GDNF-c17.2 cells in vivo and no expression was detected from $4.5 \mathrm{~d}$ to 4 months after intrastriatal grafting of the GDNF-NSCs (Fig. 3G). We also found that other c17.2 derivatives downregulated the lac $Z$ transgene at distinct time points after differentiation, suggesting that this phenomenon may be related to the integration site of the new transgene and/or to the 

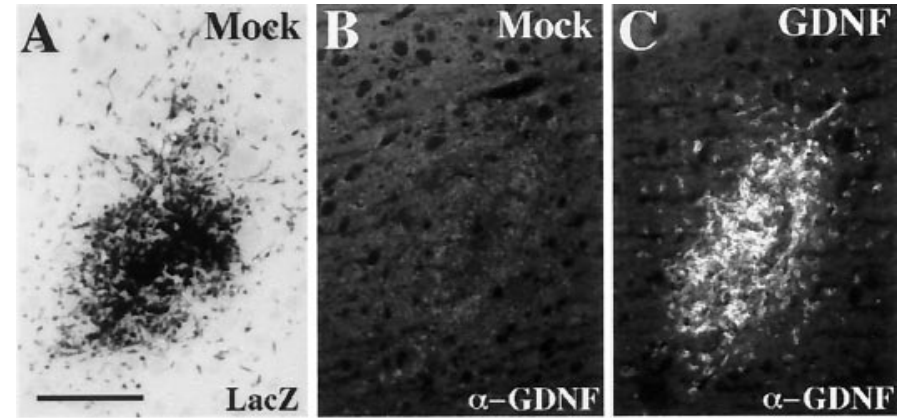

D

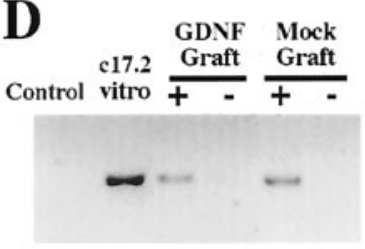

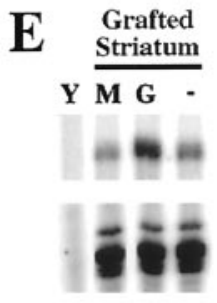

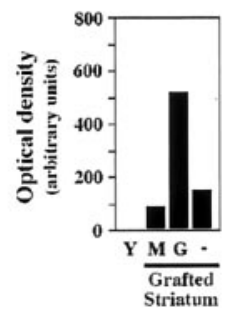

Figure 2. GDNF-c17.2 and MT-c17.2 grafted cells survive the grafting procedure well, but only GDNF-c17.2 cells express high levels of GDNF in vivo. $A-C$, MT-c17.2 and GDNF-c17.2 grafted cells in the striatum $4.5 \mathrm{~d}$ after grafting. $A, \mathrm{X}-\mathrm{Gal}$ histochemistry ( $L a c Z$ ) confirmed the presence of MT-c17.2 grafted cells. Note the migration out of the graft by some of the cells as soon as $4.5 \mathrm{~d}$. $B$, No GDNF immunoreactivity was detected in MT-c17.2 grafts on adjacent slides. $C$, GDNF immunohistochemistry showed many GDNF-positive cells in the GDNF-c17.2 grafts, which also were found migrating away from the graft site at this time point. $D$, The presence of cells in the grafted striatum was also verified at later time points ( 1 and 10 months) by PCR against the lac $Z$ vector. Cells could be detected in the GDNF or mock grafted striatum (+) but not in the contralateral striatum $(-)$. The signal was similar at 1 month (as shown in the Mock Graft) and at 10 months (shown in the GDNF Graft). Proliferating c17.2 cells (c17.2 vitro) were used as positive control, and cells not transfected with lac $Z$ expression vectors were used as negative control. $E$, Increased levels of GDNF mRNA expression could also be detected by RPA in the striatum $15 \mathrm{~d}$ after grafting of the GDNF-c17.2 cells $(G)$ but not after grafting the MT-c17.2 cells $(M)$. The levels of expression of GDNF in the nongrafted striatum $(-)$ were higher than in the control grafted striatum $(M)$ because the MT-c17.2 cells express less GDNF than the intact adult striatum. GDNF expression in the GDNFc17.2 grafted striatum was more than five times higher than in the MT-c17.2 grafted striatum. Yeast tRNA was used as negative control. Values correspond to one representative experiment $(n=2)$. Scale bar (in $A$ ): $A-C, 250 \mu \mathrm{m}$.

clonal expansion of the cells. However, the presence of grafted GDNF-c17.2 or MT-c17.2 cells could be determined in a reliable manner by PCR against the lacZ cDNA sequences, because those sequences are present in c17.2 cells (Snyder et al., 1992). As shown in Figure 2D, that technique allowed us to detect either GDNF-c17.2 or MT-c17.2 cells after grafting. In addition, the presence of GDNF-c17.2 cells in the brain was detected by GDNF immunohistochemistry (Fig. 2C) or RPA (Fig. 2E) in all animals grafted for up to 2 weeks. Interestingly, anti-GDNF antibodies were only able to detect the high levels of GDNF overexpressed by the GDNF-c17.2 cells (Fig. $3 F, H$ ) but not the basal levels of expression in MT-c17.2 cells or in the striatum (Fig. 4A). Moreover, because none of the MT-c17.2 grafted brains contained cells expressing GDNF mRNA or protein above control or contralateral grafted striata (Fig. 2B), our results indicate that grafting of the 17.2 cells does not induce GDNF expression in the host tissue. Thus, combined, our results are consistent with the notion that all cells expressing high levels of GDNF mRNA derive from the GDNF-c17.2 cells and that the
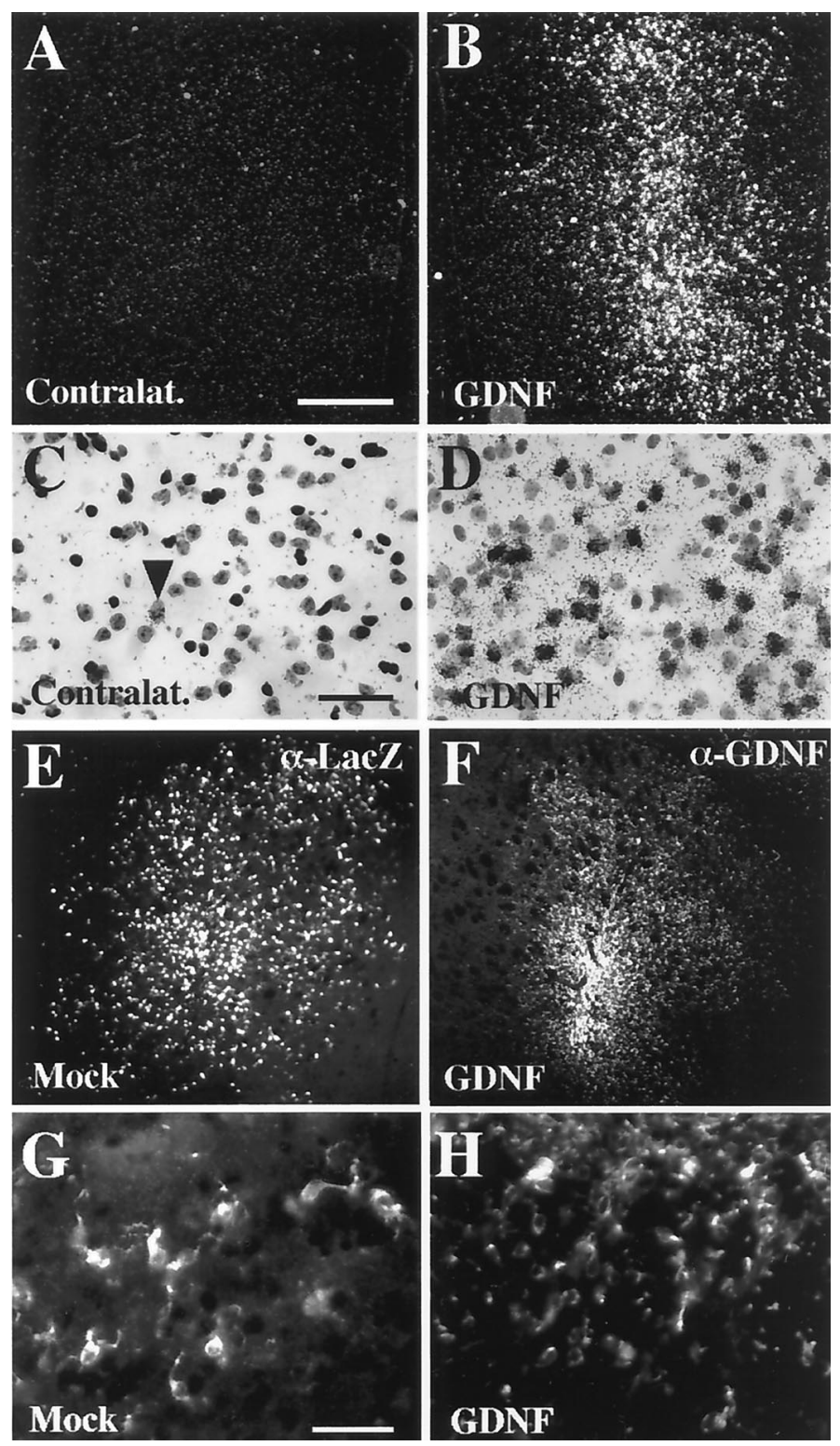

Figure 3. GDNF-c17.2 and MT-c17.2 cells engraft well and disperse within the striatum by 1 month after grafting. $A-D$, ISH showed the presence of cells expressing very high levels of GDNF mRNA in the GDNF grafted striatum $(B, D)$ but not in the contralateral side $(A, C)$. Note the abundance and dispersion of the signal in the grafted striatum $(B)$. At higher magnification and bright field $(C, D)$, it is possible to observe one endogenous GDNF-expressing cell (arrowhead in $C$ ) and many grafted cells with high levels of GDNF mRNA expression $(D)$. E, $G$, The presence of MT-c17.2 cells was verified by $\beta$-Gal immunohistochemistry against the lac $Z$ product $(\alpha-L a c)$ at $30 \mathrm{~d}$ after grafting. $\beta$-Galimmunoreactive cells (magnified in $G$ ) were detected in the ipsilateral striatum to the graft $(E) . F, H$, GDNF-c17.2 cells were also detected 1 month after grafting by GDNF immunohistochemistry. $F$, GDNF-c17.2 cells (magnified in $H$ ) displayed a similar distribution to cells expressing high levels of GDNF mRNA. Scale bars: (in $A$ ) $A, B, E, F, 500 \mu \mathrm{m}$; (in $C$ ) $C, D, 100 \mu \mathrm{m}$; (in $G$ ) $G, H, 100 \mu \mathrm{m}$.

GDNF transgene is expressed for at least 2 weeks after grafting at sustained high levels in all animals.

\section{Graft survival after intrastriatal grafting in vivo}

We next examined whether GDNF-c17.2 and MT-c17.2 cells, which have a mixed CD-1 and C57BL/6 genetic background (Snyder et al., 1992), survived for up to 4 months after grafting in 

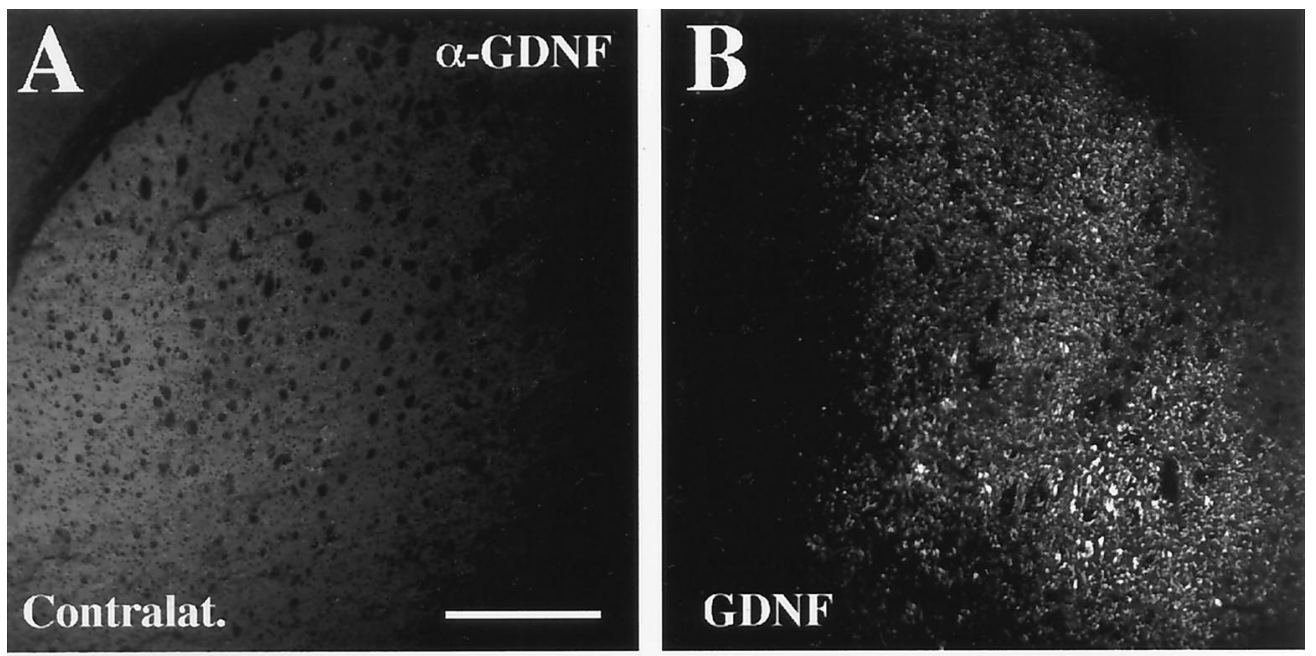

Figure 4. GDNF-c17.2 and MT-c17.2 engrafted for at least 4 months, the longest time point analyzed morphologically. $A, B$, GDNF-c17.2 cells engrafted well in the adult striatum and were detected by GDNF immunohistochemistry in the ipsilateral striatum of all nude mice but not in the contralateral striatum $(A)$. MT-c17.2 cells showed a similar pattern of engraftment and were readily detected by $\beta$-Gal immunohistochemistry against the lac $Z$ product $(\alpha-L a c) 4$ months after grafting in the ipsilateral striatum $(D)$ but not in the contralateral side $(C)$. Scale bar (in $A$ ): $A-D, 500 \mu \mathrm{m}$. $E, F$, At 4 months after grafting, we also found that GDNF-c17.2 cells differentiated and did not express the neural stem cell marker nestin $(F)$. Instead, nestin was found to be abundantly expressed by most of the grafted cells by $4.5 \mathrm{~d}(E)$. Scale bar (in $E$ ): $E, F, 100 \mathrm{~mm}$.
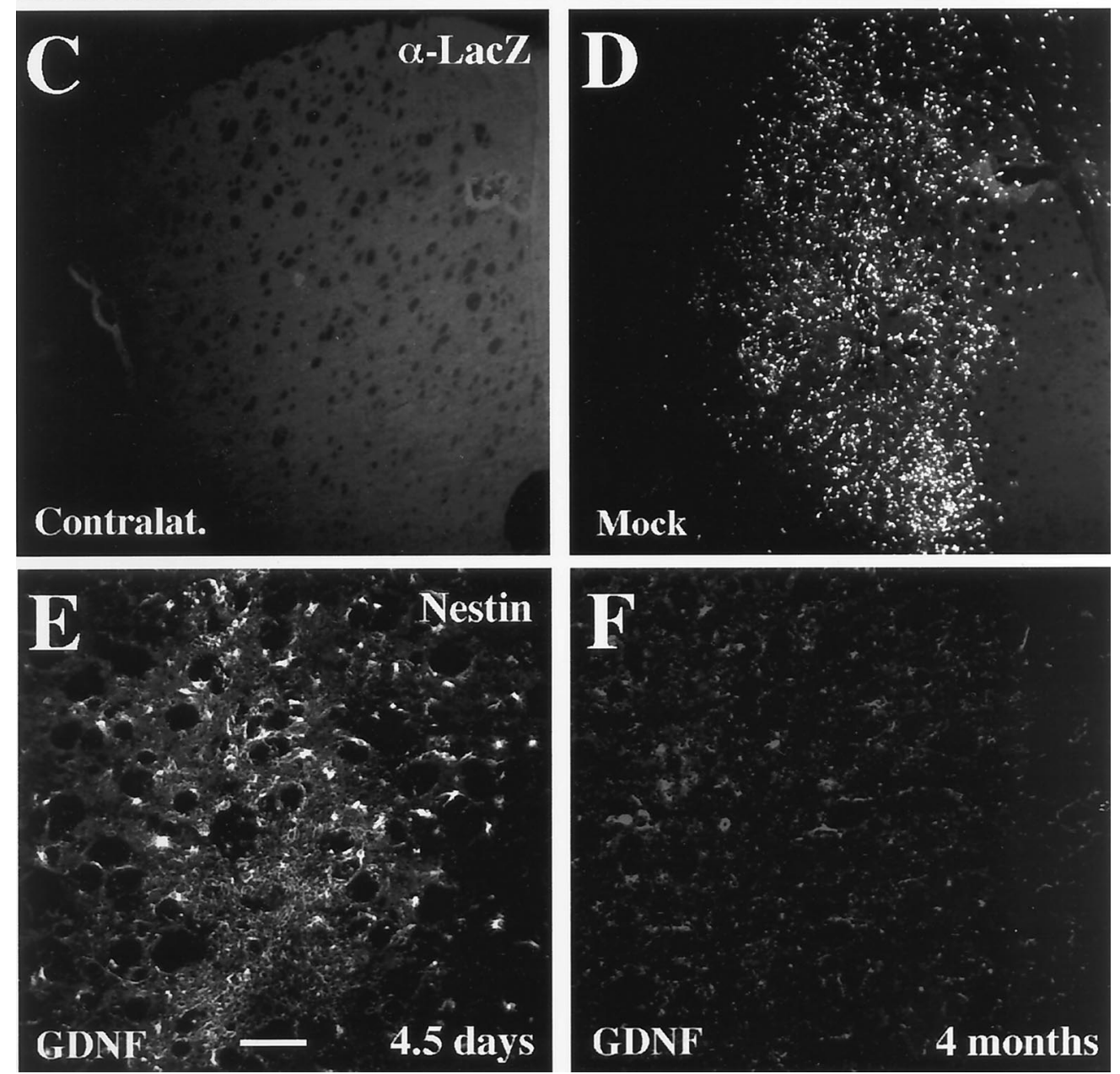

the adult striatum of CD-1 mice. The brains of animals receiving the allografts were analyzed by immunohistochemistry and/or in situ hybridization after $15 \mathrm{~d}, 1$ month, or 4 months. Fifteen days after grafting, the grafts were present in $100 \%$ of the animals receiving either the MT-c17.2 or GDNF-c17.2 grafts, as assessed by $\beta$-Gal or GDNF immunohistochemistry, respectively (Table 1). One month after grafting, both cell lines were also detected by ISH (Fig. $3 B, D$ ) or immunohistochemistry (Fig. $3 E-H$ ) in the ipsilateral side. However, only $41.6 \%(n=12)$ of the GDNF-c17.2 grafted brains and $37.5 \%(n=8)$ of the MT-c17.2 grafted brains showed positive cells at this time point (Table 1 ). This percentage of engraftment was similar to that reported previously for c17.2 cells after 6 weeks (Snyder et al., 1997) and suggested to us that engraftment in the adult brain does not depend on clonality or transgene expression but on the time after grafting. Similarly, GDNF-c17.2 cells were identified by PCR against the lacZ cDNA in one animal of three at 1 month and in one animal of four at 10 months after grafting (Fig. 2D). In agreement with this, the 


\begin{tabular}{|c|c|c|c|c|}
\hline & $\begin{array}{l}14 \mathrm{~d} \\
\text { WT }\end{array}$ & $\begin{array}{l}30 \mathrm{~d} \\
\text { WT }\end{array}$ & $\begin{array}{l}120 \mathrm{~d} \\
\text { WT }\end{array}$ & $\begin{array}{l}120 \mathrm{~d} \\
\text { Nude }\end{array}$ \\
\hline $\begin{array}{l}\text { MT-c17.2 grafts } \\
\quad(\beta \text {-Gal-positive })\end{array}$ & $\begin{array}{c}3 / 3 \\
(100 \%)\end{array}$ & $\begin{array}{c}3 / 8 \\
(37.5 \%)\end{array}$ & $\begin{array}{l}0 / 8 \\
(0 \%)\end{array}$ & $\begin{array}{c}3 / 3 \\
(100 \%)\end{array}$ \\
\hline $\begin{array}{r}\text { GDNF-c17.2 grafts } \\
\text { (GDNF-positive) }\end{array}$ & $\begin{array}{c}4 / 4 \\
(100 \%)\end{array}$ & $\begin{array}{c}5 / 12 \\
(41.6 \%)\end{array}$ & $\begin{array}{c}1 / 8 \\
(12.5 \%)\end{array}$ & $\begin{array}{c}3 / 3 \\
(100 \%)\end{array}$ \\
\hline
\end{tabular}

Animals showing $\beta$-Gal- or GDNF-immunoreactive cells in the striatum at the indicated time points were considered as positive. In general, most of the animals showed either a large engraftment (see Figs. 3, 4) or absence of positive cells. The engraftment efficiency of MT-c17.2 or GDNF-c17.2 cells was $100 \%$ in nude CD-1 mice (Nude) but declined over time in wild-type mice (WT).

percentage of animals showing engraftment at 4 months decreased even more to reach $12.5 \%(n=8)$ in animals receiving GDNF-c17.2 cells and to $0 \%(n=8)$ in animals receiving MT-c17.2 grafts (Table 1). Surprisingly, in the only animal in which cells were detected at 4 months, a full striatal engraftment was identified, suggesting that, although progressive, the cell loss process takes place as an all-or-nothing process with important individual variation. We therefore decided to examine whether the immune response of the host compromised the survival of the grafts and performed grafting experiments in CD-1 nude mice. Our results show that grafting of either GDNF-c17.2 cells (Fig. $4 B$ ) or MT-c17.2 cells (Fig. $4 D$ ) in adult nude CD-1 mice results in the engraftment of cells in $100 \%$ of the animals after 4 months (Table 1), as assessed by GDNF or $\beta$-Gal immunohistochemistry.

\section{C17.2 NSCs disperse in the adult striatum to integrate, differentiate, and give rise to distinct cell lineages}

Morphological analysis of those brains showing engraftment of either MT-c17.2 or GDNF-c17.2 NSCs at 1 month showed that MT-c17.2 and GDNF-c17.2 NSCs dispersed similarly throughout the striatum (Fig. $3 B, E, F$ ), suggesting that their ability to migrate in the brain is not impaired or enhanced by the expression of the $L a c Z$ or GDNF transgenes. Moreover, comparison of both cells at 1 and 4 months, GDNF-c17.2 (Figs. 3B, 4B) and MT-c17.2 (Figs. $3 E, 4 D)$, showed that most of the dispersion of the cells takes place within 1 month after grafting.

Because cell proliferation is enhanced by v-myc in c17.2 cells in vitro, we extensively examined whether the MT-c17.2 or GDNFc17.2 cells formed brain tumors in vivo. By now, we already grafted $>100$ adult animals, including wild-type and nude mice, and we never found brain tumors. On the contrary, consistent with differentiation in vivo, GDNF-c17.2 cells downregulate nestin expression from $4.5 \mathrm{~d}$ to 4 months after grafting, as assessed by immunohistochemistry (Fig. $4 E, F$ ). Thus, our results indicate that MT-c17.2 and GDNF-c17.2 cells differentiate in vivo as much as parental c17.2 cells do (Snyder et al., 1992). We next analyzed the phenotype that differentiated GDNF-c17.2 cells adopted after grafting, using double immunohistochemistry with antibodies against GDNF or $\beta$-Gal and NeuN to identify GDNF-c17.2- or MT-c17.2-derived neurons, GDNF or $\beta$-Gal and GFAP to identify c17.2 cell-derived astrocytes, and GDNF or $\beta$-Gal and CNPase to identify GDNF-c17.2- or MT-c17.2-derived oligodendrocytes. One month after grafting, MT-c17.2 cells were detected as $\beta$-Gal/NeuN double-positive cells (Fig. 5A), $\beta$-Gal/GFAP double-positive cells (Fig. $5 B$ ), and $\beta$-Gal/CNPase doublepositive cells (Fig. $5 C$ ). In contrast, GDNF-c17.2 grafts gave rise to few GDNF/NeuN double-positive neurons (Fig. $5 D$ ), few GDNF/GFAP double-positive astrocytes (Fig. 5E), and a high

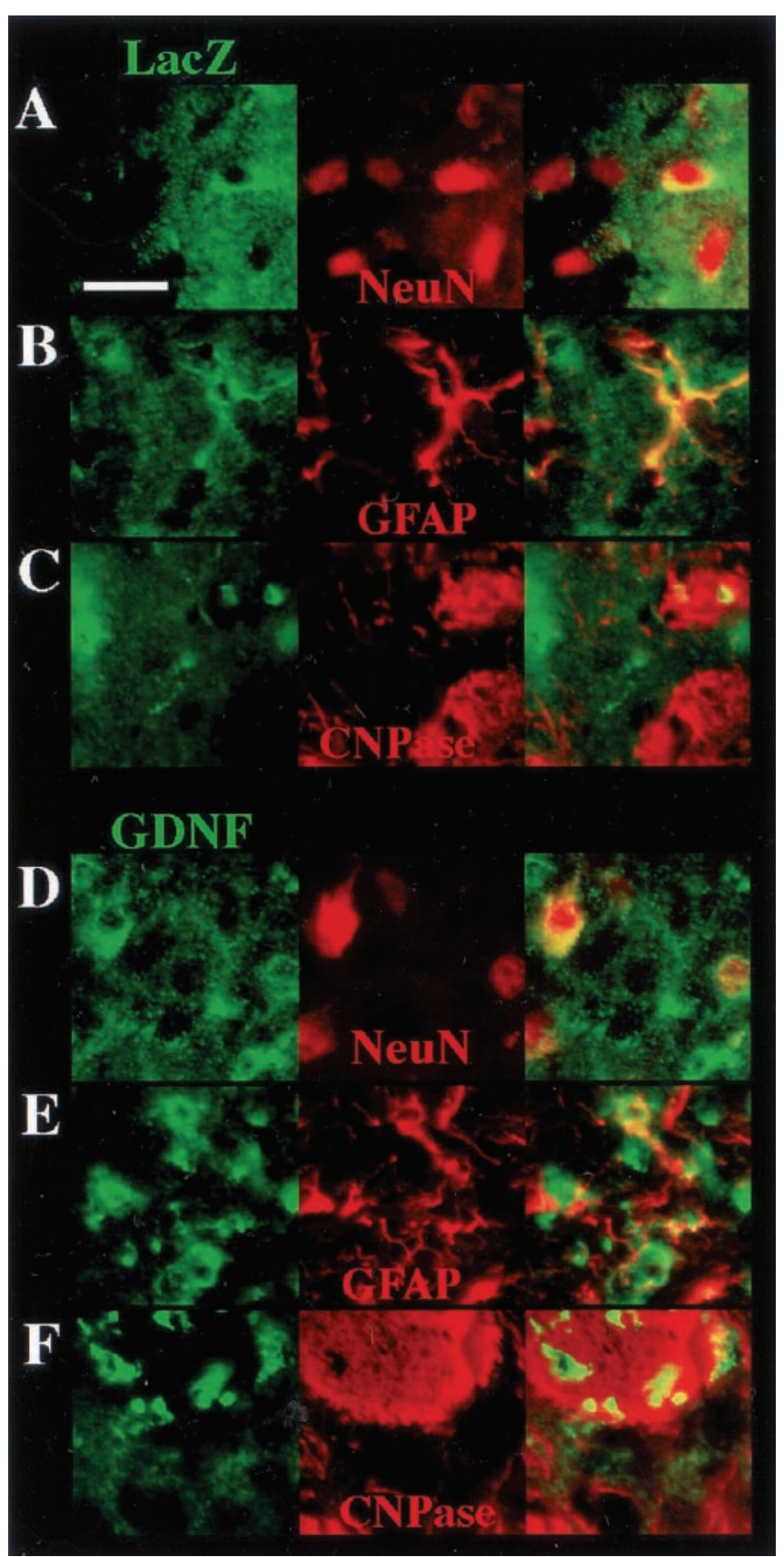

Figure 5. Double immunohistochemistry showing that MT-c17.2 $(A-C)$ and GDNF-c17.2 cells $(D-F)$ behave as multipotent NSCs after intrastriatal grafting in the adult CD-1 mice and give rise to neurons $(A, D)$, astrocytes $(B, E)$, and oligodendrocytes $(C, F) . A-C$, Double immunohistochemistry with anti- $\beta$-Gal antibodies (LacZ, in green), and antibodies against NeuN $(A)$, GFAP $(B)$, and CNPase $(C)$, all in red, showed that MT-c17.2 can give rise to all three neuronal lineages in vivo. $D-F$, Double immunohistochemistry with anti-GDNF antibodies (in green) and antibodies against $\mathrm{NeuN}(D)$, GFAP $(E)$, and CNPase $(F)$, all in red, showed that GDNF-c17.2 can give rise to all three neuronal lineages. Note that most GDNF-c17.2 cells stained with anti-CNPase antibodies, suggesting that they mainly become oligodendrocytes (see Table 2). Scale bar (in $A$ ): $A-F, 25 \mu \mathrm{m}$.

proportion ( $81 \%$ ) of GDNF/CNPase double-positive oligodendrocytes in animals grafted for 1 month (Fig. $5 F$, Table 2). This result was confirmed in animals grafted for 4 months, indicating that GDNF-c17.2 cells adopt a stable oligodendrocytic fate. 
Table 2. GDNF-c17.2 cells gave rise to a higher proportion of CNPase-positive cells than MT-c17.2 cells and located together with endogenous CNPase-positive cells within white matter fiber bundles of the internal capsule

\begin{tabular}{cccccc} 
& \multicolumn{2}{c}{ CNPase-negative cells } & & \multicolumn{2}{c}{ CNPase-positive cells } \\
\cline { 2 - 3 } & Gray matter & White matter & & Gray matter & White matter \\
\hline MT-c17.2 & $44.5 \pm 0.5$ & $3 \pm 3$ & & $3 \pm 2$ & $4.5 \pm 0.5$ \\
$(\beta$-Gal-positive cells $)$ & $(81 \%)$ & $(5.5 \%)$ & & $(5.4 \%)$ & $(8.1 \%)$ \\
GDNF-c17.2 & $7.7 \pm 2$ & $2.3 \pm 1$ & & $6.3 \pm 5$ & $39 \pm 5$ \\
$($ GDNF-positive cells $)$ & $(13.7 \%)$ & $(5.3 \%)$ & & $(11 \%)$ & $(70 \%)$
\end{tabular}

Animals were grafted with either MT-c17.2 or GDNF-c17.2 cells for 1 month. The grafted cells were identified by $\beta$-Gal or GDNF immunohistochemistry, respectively, and assessed for double labeling with anti-CNPase antibodies. Fifty-five randomly chosen $\beta$-Gal- or GDNF-positive cells were analyzed per animal in three different brains per condition. Our results show that most MT-c17.2 $\beta$-Gal-positive cells become CNPase-negative (86.4\%) and are found outside of the white matter fiber bundles $(81 \%)$. Instead, most GDNF-c17.2 cells became CNPase-positive $(81 \%)$ and are located within white matter fiber bundles $(70 \%)$.

Moreover, most GDNF-c17.2-derived cells predominantly $(75.3 \%)$ integrated within the white matter and fibers bundles of the internal capsule that transverses the striatum (Fig. $5 F$, Table 2). Instead, MT-c17.2 cells gave rise to fewer CNPase-positive oligodendrocytes $(13.5 \%)$, and only $13.6 \%$ of the MT-c17.2 cells were found in the white matter. Thus, our results show that GDNF-c17.2 NSCs retain the ability of the parental c17.2 cells to give rise to neurons and astrocytes, but they mainly give rise to oligodendrocytes after grafting in the adult striatum. Moreover, $70 \%$ of the GDNF-c17.2 cells gave rise to oligodendrocytes that incorporated in the adequate striatal compartment, that is, the white matter of the internal capsule.

\section{GDNF-expressing NSCs efficiently deliver GDNF to dopaminergic neurons}

Next, we examined whether GDNF was efficiently delivered to dopaminergic neurons in the host brain. We first examined by immunohistochemistry the diffusion of GDNF in the host striatum and only found background levels of GDNF immunoreactivity in the striatal neuropil (Fig. $3 F, H$ ). However, when the ventral midbrain was examined, we found an increase in GDNF immunoreactivity in the ipsilateral substantia nigra to the striatal GDNF graft (Fig. 6C). On the contrary, in the ipsilateral substantia nigra to a striatal mock graft, or in the contralateral side to GDNF grafts (Fig. 6D), only background levels of GDNF immunoreactivity were detected. Moreover, double $\mathrm{TH}$ and GDNF immunohistochemistry clearly showed that GDNF immunoreactivity was contained both in the substantia nigra neuropil and within dopaminergic neurons (Fig. 6E-G), suggesting that GDNF was efficiently transported in a retrograde manner by dopaminergic neurons from the striatum to the substantia nigra.

\section{GDNF-expressing NSCs prevent the loss of substantia} nigra dopaminergic neurons in a 6-OHDA model of PD

To test the therapeutic potential of the GDNF-c17.2 NSCs, we performed intrastriatal grafts in a 6-OHDA lesion model of PD. A total of $5 \times 10^{5}$ GDNF-c17.2 or MT-c17.2 cells were grafted in four deposits in the striatum (Fig. $7 A$ ). Sixteen days later, grafted and nongrafted animals received a single intrastriatal injection of $4 \mu \mathrm{g}$ of 6-OHDA. Thirty days after grafting, we characterized the neuroprotective effect of the GDNF-c17.2 NSCs on substantia nigra dopaminergic neurons. In the group of animals injected with 6-OHDA alone or with 6-OHDA and MT-c17.2, TH immunohistochemistry demonstrated a similar loss of substantia nigra dopaminergic neurons of 61 and $63 \%$, respectively (Fig. $7 B-E$ ), indicating that the NSCs had no survival-promoting effect per se.
In contrast, animals grafted with the GDNF-c17.2 NSCs demonstrated a loss of only $21 \%$ of substantia nigra dopaminergic neurons (Fig. 7B,F). Moreover, higher levels of TH immunoreactivity were also detected in the striatum of GDNF-c17.2 grafted animals (Fig. 8C) compared with 6-OHDA-lesioned or animals receiving both 6-OHDA and MT-c17.2 grafts (Fig. 8B). Thus, our results show that dopaminergic neurons of animals grafted with GDNF-c17.2 NSCs are more resistant to 6-OHDA and oxidative stress, a mechanism that has been invoked in the etiopathology of Parkinson's disease (Jenner and Olanow, 1998).
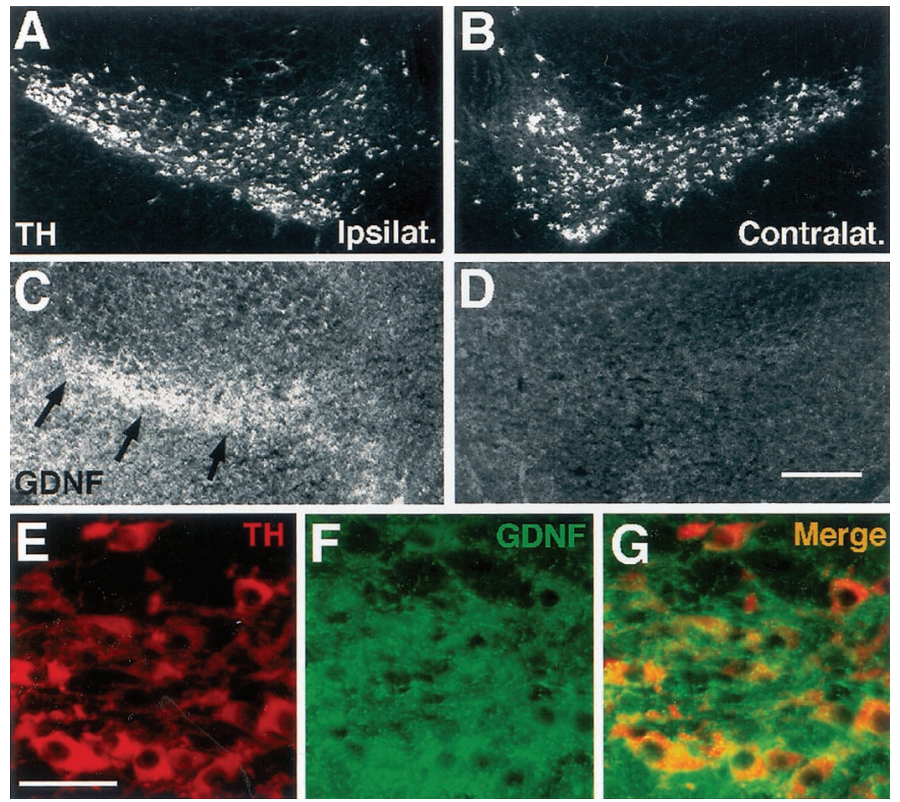

Figure 6. Intrastriatal grafting of the GDNF-c17.2 cells results in the retrograde labeling of substantia nigra dopaminergic neurons. $A-D$, Adjacent sections from the ipsilateral $(A, C)$ or contralateral $(B, D)$ substantia nigra to intrastriatal GDNF-c17.2 grafts were processed for immunohistochemistry with antibodies against TH $(A, B)$ and $\operatorname{GDNF}(C, D) 1$ month after grafting. GDNF immunoreactivity over background level was detected in the ipsilateral substantia nigra but not in the contralateral side. $E-G$, Double immunohistochemistry for TH $(E)$ and GDNF $(F)$ revealed that GDNF was contained within dopaminergic neurons in the substantia nigra pars compacta $(G)$, suggesting that GDNF was retrogradely transported by substantia nigra dopaminergic neurons from the ipsilateral striatum. Scale bars: (in $D$ ) $A-D, 250 \mu \mathrm{m}$; (in $E$ ) $E-G, 50 \mu \mathrm{m}$. 

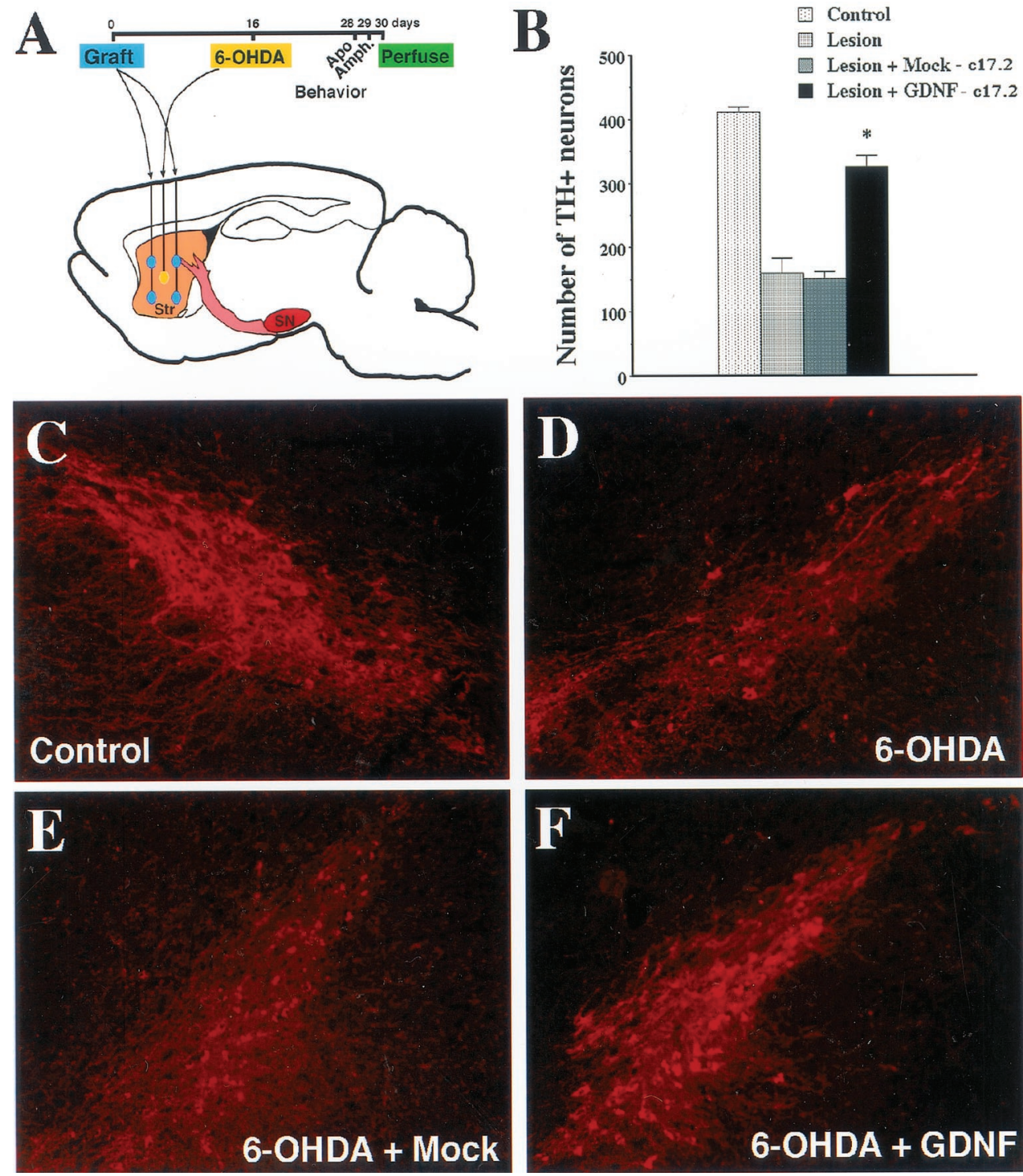

Figure 7. GDNF-c17.2 grafts protected substantia nigra dopaminergic neurons in a 6-OHDA model of Parkinson's disease. $A$, Schematic drawing of the positions at which the cells were grafted and the 6OHDA injection was performed. The contralateral side was left intact. The grafting was performed at day 0 , the 6-OHDA injection at day 16 , and perfusion at day 30. Apomorphine- and amphetamineinduced circling behavior were studied at days 28 and 29, respectively. $B$, Quantification of the number of substantia nigra TH-positive neurons in the indicated experimental conditions. Values represent the mean $\pm \operatorname{SEM}(n=5-7)$ of the number of TH-positive cells counted in serial sections through the substantia nigra. ${ }^{*} p<$ 0.0001 versus lesioned substantia nigra grafted or not with the MT-c17.2 cell line as determined by one-way ANOVA (significant effect of treatment, $p<0.0001$; $\left.F_{(3,32)}=101.1\right) . C-F$, TH immunohistochemistry showed that grafting of the MT-c17.2 cells did not prevent the loss of dopamine neurons (compare $D$ and $E$ with $C$ ). Instead, GDNF-c17.2 cells $(F)$ prevented the loss of dopamine neurons in the substantia nigra.

\section{Intrastriatal grafting of GDNF-expressing NSCs prevents behavioral abnormalities associated with unilateral 6-OHDA lesions}

To determine whether the protective effects of the GDNF-c17.2 cells translated into functional improvement, $12 \mathrm{~d}$ after lesioning we assayed the grafted animals for apomorphine-induced circling behavior. Animals receiving 6-OHDA plus GDNF-c17.2 grafts showed a $50 \%$ reduction in the number of net contralateral turns compared with the group receiving only 6-OHDA, whereas animals receiving the MT-c17.2 grafts plus 6-OHDA lesions did not show any significant reduction compared with the group receiving only 6-OHDA (Fig. 8D). The next day, animals were tested for amphetamine-induced circling behavior. Mice receiving 6-OHDA and GDNF-c17.2 grafts showed a 90\% reduction in the number of net ipsilateral turns compared with animals receiving 6-OHDA alone, whereas animals receiving the MT-c17.2 grafts and 6-OHDA lesions did not differ from the 6-OHDA group (Fig. 8E). Thus, our results are consistent with the prevention of behavioral deficits by GDNF-c17.2 cells in a 6-OHDA model of PD.

\section{DISCUSSION}

Our study shows that NSCs constitute very useful tools to deliver transgenes with therapeutic value because they locally disperse after grafting, integrate in the host adult brain, and differentiate into multiple, stable phenotypes. Furthermore, we demonstrate that NSCs can stably release high levels of GDNF for at least 4 months, preventing the degeneration of dopaminergic neurons and motor alterations in a mouse model of PD.

\section{NSCs as a tool to deliver GDNF in the adult brain}

One difficulty often encountered when expressing foreign genes in NSCs has been the downregulation of transgenes during cell differentiation (Flax et al., 1998; Benedetti et al., 2000). However, in the present study, we constructed an expression vector using a previously described $\beta$-actin promoter with a cytomegalovirus (CMV) enhancer (Niwa et al., 1991) fused to a bicistronic construct with a selectable marker and a mini-intron. The sustained high levels of transgene expression that we achieve in NSCs with this vector suggests that ex vivo gene transfer and grafting of engineered NSCs could constitute a clear alternative to direct 

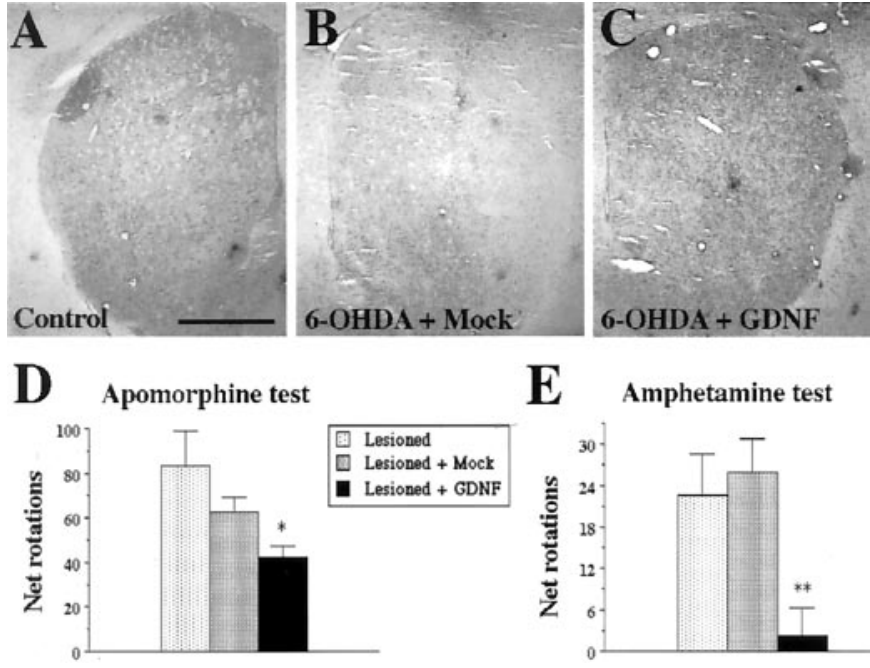

Figure 8. GDNF-c17.2 grafted cells prevented the 6-OHDA-induced reduction of $\mathrm{TH}$ staining in the striatum and behavioral abnormalities associated with unilateral 6-OHDA lesions. $A-C$, TH immunostaining in sections through the intact striatum $(A)$, the 6-OHDA lesioned and MT-c17.2 grafted striatum (B), and the 6-OHDA lesioned and GDNFc17.2 grafted striatum $(C)$. $D$, Total net apomorphine-induced rotations contralateral to the lesioned side during $5 \mathrm{~min}$ at $10 \mathrm{~min}$ after administration. ${ }^{*} p<0.01$ versus lesioned substantia nigra as determined by one-way ANOVA (significant effect of treatment, $p<0.03 ; F_{(2,15)}=$ 4.564). E, Total net amphetamine-induced rotations ipsilateral to the lesioned side during $3 \mathrm{~min}$ at 15, 30, and $45 \mathrm{~min}$ after administration. ${ }^{* *} p<0.01$ versus lesioned substantia nigra grafted or not with the MT-c17.2 cell line as determined by one-way ANOVA (significant effect of treatment, $\left.p<0.006 ; F_{(2,14)}=7.549\right)$. Scale bar (in $A$ ): $A-C, 1 \mathrm{~mm}$.

gene transfer techniques. The delivery of transgenes by NSCs has the advantages that no genetic modification is introduced in the cells of the host, no viral particles have to be introduced in the nervous system, and it allows further engineering of the cells to introduce extra safety features, such as the expression of genes to allow the selective elimination of the NSCs from the host. Moreover, because NSCs can be expanded in vitro, they can be extensively characterized and standardized to determine their quality and the efficiency and biological activity of the transgene before grafting.

One other important issue when considering the grafting of cells in the brain as a source for neuroprotective molecules is their survival. Our results show that both GDNF-NSCs and MT-NSCs engraft in the adult brain with very similar efficiency. In both cases, we found more efficient engraftment in nude mice than in wild-type mice, suggesting that, although allografts can survive in the host brain, they are targeted by the immune system. We are currently characterizing the cellular immune response of the host and studying whether standard immunosuppressive therapies can prevent the immune reaction that takes place between 2 weeks and 4 months after allografting. In the future, as an alternative to immunosuppression, strategies based on grafting of multipotent stem cells isolated from the same individual or from donors with compatible antigens could be developed.

With regard to the properties of NSCs after engraftment in the adult striatum, our results indicate that GDNF-c17.2 NSCs are able to integrate and differentiate into stable neural phenotypes. Importantly, the engraftment and differentiation of GDNF-c17.2 NSCs does not affect their ability to maintain stable levels of biologically active GDNF. Moreover, our results suggest that the high levels of GDNF do not affect to the ability of the NSCs to migrate, integrate, and survive within the striatum but seems to affect the fate of the cells derived from them. In our experiments, the only clear effect attributable to GDNF was the increase in the proportion of CNPase-positive oligodendrocytes derived from the GDNF-c17.2 (81\%) compared with the control MT-c17.2 $(13.5 \%)$ cells. Interestingly, these cells predominantly integrated in the white matter tracts within the striatum, together with host oligodendrocytes, suggesting that GDNF expression in c17.2 NSCs might either favor or promote the differentiation of NSCs into oligodendrocytes.

\section{Neuroprotection by GDNF-NSCs in a model of Parkinson's disease}

A multitude of neurotrophic factors have been found to promote the survival or prevent the degeneration of substantia nigra pars compacta dopaminergic neurons. Among them, GDNF is one of the most potent survival factors for these neurons both in vitro and in animal models of PD (Lin et al., 1993; Beck et al., 1995; Boewencamp et al., 1995; Kearns and Gash, 1995; Sauer et al., 1995; Tomac et al., 1995; Gash et al., 1996; Åkerud et al., 1999). However, GDNF has also proven to be a potent neurotrophic factor for many other populations of neurons, including motor neurons (Henderson et al., 1994; Oppenheim et al., 1995; Yan et al., 1995) and central noradrenergic neurons (Arenas et al., 1995). Thus, both the potency and the broad spectrum of biological activities of GDNF could make the activation of multiple target cells difficult to prevent. Consistent with this, intracerebroventricular administration of high doses of GDNF has been found to induce adverse effects, including weight loss in rodents (Hoane et al., 1999) and nausea, behavioral disturbances, and weight loss in human patients (Kordower et al., 1999). Thus, alternative local delivery techniques need to be developed to implement a viable therapy with this molecule. In the last years, several approaches, including the local infusion of GDNF protein (Beck et al., 1995; Boewencamp et al., 1995; Kearns and Gash, 1995; Sauer et al., 1995; Tomac et al., 1995; Gash et al., 1996), the implantation of polymer-encapsulated cells releasing GDNF (Lindner et al., 1995), and the viral-mediated GDNF gene transfer (ChoiLundberg et al., 1997; Mandel et al., 1997, 1999; Bohn et al., 1999; Bensadoun et al., 2000, Kirik et al., 2000; Kordower et al., 2000) have been found to exert neuroprotective and/or neuroregenerative effects on dopaminergic neurons in animal models of Parkinson's disease. Neural stem cells have been successfully engineered to deliver other neurotrophic factors and have been proven to be effective in neuroprotective strategies (MartínezSerrano and Björklund, 1997), but to our knowledge, the ability of neurotrophic factors released by neural stem cells to prevent the degeneration of adult substantia nigra dopaminergic neurons in a model of Parkinson's disease has not been examined previously. Our results suggest that transplantation of engineered NSCs could be an effective and viable strategy to locally deliver GDNF in the brain, because GDNF-expressing NSCs integrated and differentiated well after grafting, dispersed within, but remained restricted to, the striatum, and maintained GDNF expression for at least 4 months. Moreover, although the dose of cells grafted provided no more than $50 \mathrm{ng} / \mathrm{d}$ of GDNF and no accumulation of GDNF was observed in the striatum, we observed retrograde transport of GDNF by substantia nigra dopaminergic neurons and a full biological response to the factor, which resulted in the protection of dopaminergic neurons and the prevention of motor disturbances in the absence of noticeable body weight loss or other adverse effects. 
It is important to note that, in the intrastriatal 6-OHDA model that we performed, the degeneration of dopaminergic neurons starts by the terminals and after 2 weeks yields a $60 \%$ loss of dopaminergic neurons and a behavioral deficit, as assessed in the apomorphine- and amphetamine-induced rotation tests. This model would correspond in humans to an early-stage PD characterized by a predominant loss of dopaminergic terminals in the striatum, a $50 \%$ cell loss in the substantia nigra, and initial motor symptoms (Fearnley and Lees, 1991). In this model, we found increased survival of nigral dopaminergic neurons and improved behavioral performance in animals lesioned with 6-OHDA and grafted with the GDNF-NSCs, which is consistent with a neuroprotective action of GDNF. This result differs form other studies exploring the regenerative properties of GDNF, in that the improvement of the motor performance takes place at later stages, when axons regenerate in response to GDNF (Bensadoun et al., 2000; Kirik et al., 2000). Thus, our results show that administration of GDNF by GDNF-c17.2 cells efficiently prevents the retrograde degeneration of dopaminergic axons, the loss of dopaminergic neurons, and the early motor deficits associated to them.

In conclusion, the experiments presented here demonstrate that NSCs can be efficiently engineered to deliver therapeutic levels of transgenes to target tissues for at least 4 months in vivo. Moreover, NSCs engineered to deliver GDNF were found to prevent the degeneration of dopaminergic neurons and the behavioral impairment in a model of PD. In such a way, our results demonstrate that GDNF-NSCs are particularly effective at protecting dopamine neurons in a model of PD and suggest that strategies based on the local delivery of neurotrophic factors by NSCs may find an application in the treatment of Parkinson's disease.

\section{REFERENCES}

Åkerud P, Alberch J, Eketjäll S, Wagner J, Arenas E (1999) Differential effects of GDNF and Neurturin on developing and adult substantia nigra dopaminergic neurons. J Neurochem 73:70-78.

Arenas E, Trupp M, Åkerud P, Ibáñez CF (1995) GDNF prevents degeneration and promotes the phenotype of brain noradrenergic neurons in vivo. Neuron 15:1465-1473.

Barneoud P, Parmentier S, Mazadier J, Miquet JM, Boireau A, Dubedat P, Blanchard J-C (1995) Effects of complete and partial lesions of the dopaminergic mesotelencephalic system on skilled forelimb use in the rat. Neuroscience 67:837-848.

Beck K, Valverde J, Alexi T, Poulsen K, Moffat B, Vandlen R, Rosenthal A, Hefti F (1995) Mesencephalic dopaminergic neurons protected by GDNF from axotomy-induced degeneration in the adult brain. Nature 373:339-341.

Benedetti S, Pirola B, Pollo B, Magrassi L, Bruzzone MG, Rigamonti D, Galli R, Selleri S, Di Meco F, De Fraja C, Vescovi A, Cattaneo E, Finocchiaro G (2000) Gene therapy of experimental brain tumors using neural progenitor cells. Nat Med 6:447-450.

Bensadoun JC, Deglon N, Tseng JL, Ridet JL, Zurn AD, Aebischer P (2000) Lentiviral vectors as a gene delivery system in the mouse midbrain: cellular and behavioral improvements in a 6-OHDA model of Parkinson's disease using GDNF. Exp Neurol 164:15-24.

Bernheimer H, Birkmayer W, Hornykiewicz O, Jellinger K, Seitelberger F (1973) Brain dopamine and the syndromes of Parkinson and Huntington. Clinical, morphological and neurochemical correlations. J Neurol Sci 20:415-455.

Björklund A, Lindvall O (2000) Cell replacement therapies for central nervous system disorders. Nat Neurosci 6:537-544.

Boewencamp KE, Hoffman AF, Gerhardt GA, Henry MA, Biddle PT, Hoffer BJ, Granholm ACE (1995) Glial cell line-derived neurotrophic factor supports survival of injured midbrain dopaminergic neurons. J Comp Neurol 355:479-489.

Bohn MC, Choi-Lundberg DL, Davidson BL, Leranth C, Kozlowski DA, Smith JC, O'Banion MK, Redmond DE (1999) Adenovirus-mediated transgene expression in nonhuman primate brain. Hum Gene Ther 10:1175-1184.

Carlsson A (1993) Thirty years of dopamine research. Adv Neurol 60:1-10.
Carpenter MK, Cui X, Hu ZY, Jackson J, Sherman S, Seiger A, Wahlberg LU (1999) In vitro expansion of a multipotent population of human neural progenitor cells. Exp Neurol 158:265-278.

Choi-Lundberg DL, Lin Q, Chang YN, Chiang YL, Hay CM, Mohajeri H, Davidson BL, Bohn MC (1997) Dopaminergic neurons protected from degeneration by GDNF gene therapy. Science 275:838-841.

Daadi MM, Weiss S (1999) Generation of tyrosine hydroxylaseproducing neurons from precursors of the embryonic and adult forebrain. J Neurosci 19:4484-4497.

Dunnett S, Björklund A (1999) Prospects for new restorative and neuroprotective treatments in Parkinson's disease. Nature [Suppl] 399:A32-A39.

Fearnley JM, Lees AJ (1991) Ageing and Parkinson's disease: substantia nigra regional selectivity. Brain 114:2283-2301.

Flax JD, Aurora S, Yang C, Simonin C, Wills AM, Billinghurst LL Jendoubi M, Sidman RL, Wolfe JH, Kim SU, Snyder EY (1998) Engraftable human neural stem cells respond to developmental cues, replace neurons, and express foreign genes. Nat Biotech 16:1033-1039.

Gage FH (2000) Mammalian neural stem cells. Science 287:1433-1438.

Gash DM, Zhang Z, Ovadia A, Cass WA, Yi A, Simmerman L, Russel D, Martin D, Lapchak PA, Collins F, Hoffer BJ, Gerhardt GA (1996) Functional recovery in parkinsonian monkeys treated with GDNF. Nature 380:252-255.

Henderson CE, Phillips HS, Pollock RA, Davies AM, Lemeulle C, Armanini M, Simpson LC, Moffet B, Vandlen RA, Koliatsos VE, Rosenthal A (1994) GDNF: a potent survival factor for motoneurons present in peripheral nerve and muscle. Science 266:1062-1064.

Hoane MR, Gulwadi AG, Morrison S, Hovanesian G, Lindner MD, Tao W (1999) Differential in vivo effects of neurturin and glial cell-linederived neurotrophic factor. Exp Neurol 160:235-243.

Hornykiewicz O (1993) Parkinson's disease and the adaptive capacity of the nigrostriatal dopamine system: possible neurochemical mechanisms. Adv Neurol 60:140-147.

Jenner P, Olanow CW (1998) Understanding cell death in Parkinson's disease. Ann Neurol 44 [Suppl 1]:S72-S84.

Kawasaki H, Mizuseki K, Nishikawa S, Kaneko S, Kuwana Y, Nakanishi S, Nishikawa SI, Sasai Y (2000) Induction of midbrain dopaminergic neurons from ES cells by stromal cell-derived inducing activity. Neuron 28:31-40.

Kearns CM, Gash DM (1995) GDNF protects nigral dopamine neurons against 6-hydroxydopamine in vivo. Brain Res 672:104-111.

Kirik D, Rosenblad C, Björklund A, Mandel RJ (2000) Long-term rAAV-mediated gene transfer of GDNF in the rat Parkinson's model intrastriatal but not intranigral transduction promotes functional regeneration in the lesioned nigrostriatal system. J Neurosci 20:4686-4700.

Kordower JH, Freeman TB, Chen EY, Mufson EJ, Sanberg PR, Hauser RA, Snow B, Olanow CW (1998) Fetal nigral grafts survive and mediate clinical benefit in a patient with Parkinson's disease. Mov Disord 13:383-393.

Kordower JH, Palfi S, Chen EY, Ma SY, Sendera T, Cochran EJ, Cochran EJ, Mufson EJ, Penn R, Goetz CG, Comella CD (1999) Clinicopathological findings following intraventricular glial-derived neurotrophic factor treatment in a patient with Parkinson's disease. Ann Neurol 46:419-424.

Kordower JH, Emborg ME, Bloch J, Ma SY, Chu Y, Leventhal L, McBride J, Chen EY, Palfi S, Roitberg BZ, Brown WD, Holden JE, Pyzalski R, Taylor MD, Carvey P, Ling Z, Trono D, Hantraye P, Deglon N, Aebischer P (2000) Neurodegeneration prevented by lentiviral vector delivery of GDNF in primate models of Parkinson's disease. Science 290:767-773.

Laird PW, Zijderveld A, Linders K, Rudnicki MA, Jaenisch R, Berns A (1991) Simplified mammalian DNA isolation procedure. Nucleic Acids Res 19:4293.

Lee SH, Lumelsky N, Studer L, Auerbach JM, McKay RD (2000) Efficient generation of midbrain and hindbrain neurons from mouse embryonic stem cells. Nat Biotechnol 18:675-679.

Lin LFH, Doherty D, Lile J, Bektesh S, Collins F (1993) GDNF: a glial cell line-derived neurotrophic factor for midbrain dopaminergic neurons. Science 260:1130-1132.

Lindner MD, Winn SR, Baetge EE, Hammang JP, Gentile FT, Doherty E, McDermott PE, Frydel B, Ullman MD, Schallert T (1995) Implantation of encapsulated catecholamine and GDNF-producing cells in rats with unilateral dopamine depletions and parkinsonian symptoms. Exp Neurol 132:62-76.

Lindvall O (1999) Cerebral implantation in movement disorders: state of the art. Mov Disord 14:201-205.

Ling ZD, Potter ED, Lipton JW, Carvey PM (1998) Differentiation of mesencephalic progenitor cells into dopaminergic neurons by cytokines. Exp Neurol 149:411-423.

Mandel RJ, Spratt SK, Snyder RO, Leff SE (1997) Midbrain injection of recombinant adeno-associated virus encoding rat glial cell line-derived neurotrophic factor protects nigral neurons in a progressive 6-hydroxydopamine-induced degeneration model of Parkinson's disease in rats. Proc Natl Acad Sci USA 94:14083-14088. 
Mandel RJ, Snyder RO, Leff SE (1999) Recombinant adeno-associated viral vector-mediated glial cell line-derived neurotrophic factor gene transfer protects nigral dopamine neurons after onset of progressive degeneration in a rat model of Parkinson's disease. Exp Neurol 160:205-214.

Martínez-Serrano A, Björklund A (1997) Immortalized neural progenitor cells for CNS gene transfer and repair. Trends Neurosci 20:530-538.

McGeer PL, Itagaki S, Akiyama H, McGeer EG (1988) Rate of cell death in parkinsonism indicates active neuropathological process. Ann Neurol 24:574-576.

McKay R (1997) Stem cells in the central nervous system. Science 276:66-71.

Niwa H, Yamamura K, Miyazaki J (1991) Efficient selection for highexpression transfectants with a novel eukaryotic vector. Gene 108:193-200.

Olanow CW, Tatton WG (1999) Etiology and pathogenesis of Parkinson's disease. Annu Rev Neurosci 22:123-144.

Olanow CW, Kordower JH, Freeman TB (1996) Fetal nigral transplantation as a therapy for Parkinson's disease. Trends Neurosci 19:102-109.

Oppenheim R, Houenou L, Johnson J, Lin LF, Li L, Lo A, Newsome A, Prevette D, Wang S (1995) Developing motor neurons rescued from programmed cell death by GDNF. Nature 373:344-346.

Ostenfeld T, Caldwell MA, Prowse KR, Linskens MH, Jauniaux E, Svendsen CN (2000) Human neural precursor cells express low levels of telomerase in vitro and show diminishing cell proliferation with extensive axonal outgrowth following transplantation. Exp Neurol $164: 215-226$

Piccini P, Brooks DJ, Björklund A, Gunn RN, Grasby PM, Rimoldi O, Brundin P, Hagell P, Rehncrona S, Widner H, Lindvall O (1999) Dopamine release from nigral transplants visualized in vivo in a Parkinson's patient. Nat Neurosci 2:1137-1140.

Sauer H, Rosenblad C, Björklund A (1995) Glial cell line-derived neurotrophic factor but not transforming growth factor $\beta 3$ prevents delayed degeneration of nigral dopaminergic neurons following striatal 6-hydroxydopamine lesion. Proc Natl Acad Sci USA 92:8935-8939.

Snyder EY, Macklis JD (1996) Multipotent neural progenitor or stemlike cells may be uniquely suited for therapy for some neurodegenerative conditions. Clin Neurosci 3:310-316.
Snyder EY, Deitcher DL, Walsh C, Arnold-Aldea S, Hartwieg EA, Cepko CL (1992) Multipotent neural cell lines can engraft and participate in development of mouse cerebellum. Cell 68:33-51.

Snyder EY, Yoon C, Flax JD, Macklis JD (1997) Multipotent neural precursors can differentiate toward replacement of neurons undergoing targeted apoptotic degeneration in adult mouse neocortex. Proc Natl Acad Sci USA 94:11663-11668.

Studer L, Tabar V, McKay RDG (1998) Transplantation of expanded mesencephalic precursors leads to recovery in parkinsonian rats. Nat Neurosci 1:290-295.

Studer L, Csete M, Lee SH, Kabbani N, Walikonis J, Wold B, McKay R (2000) Enhanced proliferation, survival, and dopaminergic differentiation of CNS precursors in lowered oxygen. J Neurosci 20:7377-7383.

Tomac A, Lindqvust E, Lin LF, Ögren S, Young D, Hoffer B, Olson L (1995) Protection and repair of the nigrostriatal dopaminergic system by GDNF in vivo. Nature 373:335-339.

Trupp M, Rydén M, Jörnvall H, Timmusk T, Funakoshi H, Arenas E, Ibáñez CF (1995) Peripheral expression and biological activities of GDNF, a new neurotrophic factor for avian and mammalian peripheral neurons. J Cell Biol 130:137-148.

Trupp M, Belluardo N, Funakoshi H, Ibáñez CF (1997) Complementary and overlapping expression of glial cell line-derived neurotrophic factor (GDNF), c-ret proto-oncogene, and GDNF receptor- $\alpha$ indicates multiple mechanisms of trophic actions in the adult rat CNS. J Neurosci $17: 3554-3567$.

Wagner J, Åkerud P, Castro DS, Holm PC, Canals JM, Snyder EY, Perlmann T, Arenas E (1999) Induction of a midbrain dopaminergic phenotype in Nurr1-overexpressing neural stem cells by type 1 astrocytes. Nat Biotechnol 17:653-659.

Weiss S, Reynolds BA, Vescovi AL, Morshead C, Craig CG, van der Kooy D (1996) Is there a neural stem cell in the mammalian forebrain? Trends Neurosci 19:387-393.

Winkler JD, Weiss B (1996) Reversal of supersensitive apomorphineinduced rotational behavior in mice by continuous exposure to apomorphine. J Pharmacol Exp Ther 238:242-247.

Yan Q, Matheson C, Lopez O (1995) In vivo neurotrophic effects of GDNF on neonatal and adult facial motor neurons. Nature 373 341-344. 